\title{
ニフェジピン製剤の品質試験
}

\author{
曽根 賢, 下山律子, 照井聖比古, 藤田 昂 \\ 弘前大学医学部附属病院薬郕部*
}

\section{Quality Test of Commercial Nifedipine Preparations}

\author{
KeN SONE, Ritsuko SHIMOYAMA, KIYOHIKo \\ TERUI, and Ko FUJITA \\ Hospital Pharmacy, Hirosaki University School of Medicine*
}

(Received February 21, 1983)

\begin{abstract}
The quality of 3 kinds of tablets and capsules of commercial nifedipine preparations was evaluated in 5 tests : content uniformity, weight variation, disintegration, hardness and dissolution.

Following results were obtained; 1 ) In the weight variation test and the disintegration test, all the preparations tested met the criteria of J.P. X. 2) There was no correlation between hardness and disintegration time. 3) In the content uniformity test, the mean contents of all preparations tested were almost equal to the indicated content; however, in one preparation $p$-hydroxybenzoic acid derivatives added to the capsule were dissolved in the contents and interfered with the determination of nifedipine under the analytical condition applied to the others. Consequantly, it was necessary to find another analytical condition for this preparation. 4) The dissolution ratios of $\mathbf{5}$ kinds of preparations were good, but that of one tablet showed low tendency compared with those of the others at every measurement.
\end{abstract}

Keywords_-nifedipine; quality test; Sartorius Solubility Simulator; high performance liquid chromatography; $p$-hydroxybenzoic acid derivatives

\section{は じめに}

ハイイアペイラビリティーは薬郕を経口投与する場 合, 薬剤による合理的で科学的な治療を実現するのに最 も大切な問題であり, そのために適切な薬剤の品質管理 が必要とされている．ところで，バイオアベイラビリテ

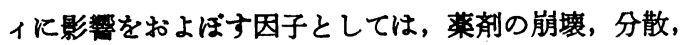
溶出，吸収などがあげられているが，近年薬剤の品質管 理が適切になされているかどうかを検討するために，特 に薬䠼の溶出試験や血中濃度の測定が盛んに行われるよ らになった。

今回著者らは，わが国において発売されている約20銘 柄のニフェジピン（以下,Nif.と略す.）製剤のうち，当 院で使用されているすのを含めてそれぞれ 3 銘柄ずつの 錠剤とカプセル剤を選び，それらの品質を溶出試験を中

* 弘前市本町 53; 53, Honcho, Hirosakî-shi, 036 Japan
心に検討したのでその成績を報告する．

\section{実 験 方 法}

\section{1. 试 料}

Table 1 亿示したとおり，6 銘柄の錠剤，カプセル剂 を試料とした。

\section{Nif. の定量}

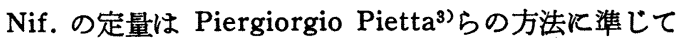
行った.すなわち，まず内部標準物質（以下,I.S. と略 す.）としてp-ジメチルアミノベンズアルデヒド（特 級）を用い，その約 $1 \mathrm{~g}$ を精密化秤量して褐色メスフラ スコに入れメタノール（液体クロマトグラフ用）に溶 解して正確に全量を $100 \mathrm{ml}$ として (原液), 冷蔵庫内に保 存した.

次に Nif.の純品約10mgを精密に秤量して褐色メスフ ラスコに入れこれを少量のメタノールに溶解し，これ にI.S. 溶液 $1 \mathrm{ml}$ を加えメタノールで全量を正確に 100 
Table 1. Nifedipine Preparations Used in the Tests

\begin{tabular}{cccccc}
\hline \hline Preparation & Lot No. & dosage form & $\begin{array}{c}\text { properties of contents } \\
\text { (capsule) }\end{array}$ & color of packing \\
\hline A & FX42X20 & film coated T. & orange \\
B & AG2700 & " & - & " \\
C & N061001 & uncoated T. & liquid & transparent \\
D & B196 & soft C. & " & red \\
E & N188210 & " & hard C. & powder & transparent \\
\hline
\end{tabular}

T : tablet C : capsule Indicated content : $10 \mathrm{mg}$

$\mathrm{ml}$ とした(標準溶液).

Nif. の定量には高速液体クロマトグラ フ装置（LCP 350, 日本分光) を用いた. 測定は Finepak SIL $\mathrm{C}_{18}-10$ (日本分光) を充てんした内径 $4.6 \mathrm{~mm}$, 長さ $250 \mathrm{~mm}$ の カラムを用い，50\%リン酸溶液で $\mathrm{pH}$ を 6.1 に調整した $0.01 \mathrm{M}$ リン酸二ナトリウム緩衝液とメタノールの混合 溶液(45:55) を移動相溶媒とし, 流速を $2 \mathrm{ml} / \mathrm{min}$ とし て室温で行い, 254nm で検出した. なお, 移動相溶媒は 5 分間脱気して用いた。

Nif. 量の計算には DP-L220，Data Processor LCを 用い,ファイル作成にあたりあらかじめ保持時間 (I.S. 5.89 分, Nif. 10.35分) を求めておき，1点検量線によ る修正内部標準法のファイルを作成し，マイクロシリン ジで Nif. 標準溶液または試料溶液をそれぞれ $10 \mu 1$ 注入 した。また， $10 \mu \mathrm{g} / \mathrm{ml}$ および $20 \mu \mathrm{g} / \mathrm{ml}$ の Nif. 標準溶液 を注入した得られた検量線は，原点を通る直線となるこ とを確認した.なお，定量は赤外線ランプ照射下で行っ た。

\section{3. 含再侙験}

1）製剤 $\mathrm{E}$ 以外の場合

試料溶液の調製は次のように行った。すなわち, 錠剤 は乳鉢でよくすりつぶして褐色メスフラスコに入れ，約 $20 \mathrm{ml}$ のメタノールを加えて溶解した，次に，同じメス フラスコに乳鉢および乳棒の付着物を少量のメタノール で数回洗浄しながら移し，I. S. 溶液 $1 \mathrm{ml}$ を加えてから メタノールで全量を正確に $100 \mathrm{ml}$ とした.

軟カプセル剤は注意しながらハサミで切断して，ま た, 硬カプセル阂はカプセルを開いてそれぞれの内容物
を $50 \mathrm{ml}$ のビーカーに入れ，約 $20 \mathrm{ml}$ のメタノールを加え て溶解し，溶液を褐色メスフラスコに移した．次に同じ メスフラスコにハサミ，カプセル，ビーカー等の付着物 を少量のメタノールで数回洗浄しながら移し，I.S. 溶液 $1 \mathrm{ml}$ を加えてから, 全量を正確に $100 \mathrm{ml}$ とした. 次に メスフラスコをときどき振とらしながら 1 時間室温に放 置した後, 不溶分をろ過（東洋ろ紙 No. 7 直径 $7 \mathrm{~cm}$ ) し, ろ液を用いて検量線作製の場合と同様に Nif. を定量し た.なお，定量には最初の一部分をすてた後のろ液を用 いた.

各試料10個について試験を行い，その平均值を表示量 に対する百分率で表わした，なお，実験はすべて赤外線 ランプ照射下で行った.

2）製剂 Eの場合

1）と同じ条件では Nif. の定量が不可能であるため, I.S. をフェナセチン $(0.1 \mathrm{mg} / \mathrm{ml})$ に, 移動相溶媒を $0.01 \mathrm{M}$ リン酸二ナトリウム緩衝液とメタノールの混合溶 液 $(50: 50)$ に, 流速を $2.8 \mathrm{ml} / \mathrm{min}$ に変えて行った.

\section{I国倔童試聒}

「日局10」錠斉重量偏差試験法に従い，試料をそれぞ れ20個ずつ用いて行った.

\section{5. 崩壊侙験}

崩壊試験器を用い「日局10」崩壊試験法に従い, それ ぞれ 6 個ずつの試料を用いて 2 回ずつ試験を行い，その 平均值で示した。な扣試験液は，崩壊試験液第 1 液（以 下，第 1 液と略す.）を用いた。

\section{6. 铝度試験}

モンサント型錠㶡用硬度計を用い破壊強度に圧縮し， 
それぞれ20個ずつの試料について測定し，その平均値で 示した.

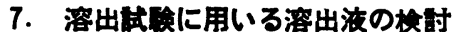

Nif.はきわめて水に溶けにくいため, 溶解補助阂とし てメタノールを用い,これと第 1 液を $9: 1,8: 2$ およ び $7: 3$ (体積比) の割合に混合した 3 種類の溶液を溶 出液とし, 試料Dを用いて溶出曲線を作成して検討を加 えた。

\section{8. 溶出試誒}

ザウトリウス溶出試験器 (以下,S.S.S. と略す.) を用 いて行った. すなわち, 内径 $100 \mathrm{ml}$ の solution chamber 中に内径 $8 \mathrm{~mm}$ のガラス球 $170 \mathrm{~g}$ と第 1 液 $70 \mathrm{ml}$ を入れ $37^{\circ}$ $\pm 1^{\circ} \mathrm{C}$ に保温する. 次いで錠剤またはカプセル剤 1 個を 入れ, ゆっくり 5 分間回転一反転の往復回転運動を行っ た. 5 分後すみやかに $30 \mathrm{ml}$ のメタノールを追加し, 回 転運動を続行した. 溶出液はフラクションコレクター によりメンブランフィルター(Type 1132 pore sige $3 \mu$, ザウトリウス）を通して $2.5 \mathrm{ml}$ ずつ $5,10,15,20,25$ 分 およひ30分に自動的にサンプリングを行った．また，実 験中 solution chamber 内の液量を一定にするために採 取量と同量の試験液を storage chamber より補充し た. 溶出液中の Nif. 量は高速液体クロマトグラフ装置 を用いて測定し, S.S.S. 法に定められた公式に従って 溶出\%を算出し, 表示量に対する溶出率(\%)として表わ した.

次にその算出法を示す.

(a) 測定した值から $1 \mathrm{ml}$ 中の $\mathrm{mg}$ 数を算出し，これを Ci とする. (b) T時間までに集められた薬物の総林数を MF とす る.

$$
\sum_{i=0}^{c=n-1} \mathrm{Ci}, 2.5 \text { (採取量) } \cdots \cdots \cdots \cdot \mathrm{MF}(\mathrm{mg})
$$

（c） T時間までに 溶解槽に溶解した薬物の総 $\mathrm{mg}$ 数を MG とする.

$$
100 \mathrm{Ci}+\mathrm{MF}(\mathrm{T}) \cdots \cdots . . . \mathrm{MG}(\mathrm{T}) \text { (mg) }
$$

(d) $\mathrm{T}$ 時間までの溶出パーセント

$$
\text { MG (T) } / \text { 主薬含量 }(\mathrm{mg}) \times 100
$$

試験はそれぞれの試料について 6 回行い，その平均值 を求めた.なお，実験はすべて赤外線ランプ照射下で行 った。

\section{実験結果および考㝝}

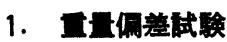

製剤 $\mathrm{A}$ と B 定はないが, 錠阂で標準偏差は 2.2 3.4mg, カプセル斉 で標準偏差は 2.9〜15.0mg であり, 軟カプセル阂のバラ ツキが比較的大きかった (Table 2).

\section{2. 溯散試験と硬度試験}

崩壊試験では各試料とも局方の規定に適合していた。 また, 硬度と崩壊時間の間には相関はみられなかった. (Table 3)

\section{3. 含田試験}

Nif.を実験方法 3，1)の条件で定量した結果，定量值 は製剤 A， B， C，D，Fではほぼ表示量值に近似して

\begin{tabular}{|c|c|c|c|c|c|}
\hline Preparation & Mean & (mg) & Max. (mg) & Min. (mg) & C.V. (\%) \\
\hline A & 158.6 & $(3.4)$ & 163.9 & 152.8 & 2.1 \\
\hline B & 120.1 & $(2.2)$ & 127.5 & 118.1 & 1.8 \\
\hline C & 399.6 & $(3.3)$ & 404.9 & 392.5 & 0.8 \\
\hline D & 402.4 & $(12.7)$ & 426.8 & 372.5 & 3.2 \\
\hline $\mathbf{E}$ & 415.4 & $(15.0)$ & 449.4 & 384.6 & 3.6 \\
\hline $\mathbf{F}$ & 227.4 & $(2.9)$ & 234.2 & 222.7 & 1.3 \\
\hline
\end{tabular}

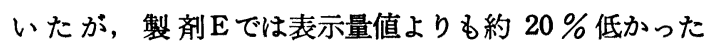

Table 2. Results of Weight Variation Test 
Table 3. Results of Disintegration Test and Hardness Test

\begin{tabular}{|c|c|c|c|}
\hline Preparation & Disintegration & Hardness of & $\begin{array}{l}\text { tablets } \\
\qquad\left(\mathrm{Kg} / \mathrm{cm}^{2}\right)\end{array}$ \\
\hline A & 7.0 & 5.7 & $0.9)$ \\
\hline B & 22.0 & 6.3 & $0.8)$ \\
\hline C & 3.0 & 10.5 & $0.7)$ \\
\hline $\mathrm{D}$ & 3.0 & - & \\
\hline$E$ & 4.0 & - & \\
\hline$F$ & 3.0 & - & \\
\hline
\end{tabular}

(Table 4).

ところで,この条件でNif.を定量すると,製剤 $\mathrm{E}$ の場合 に他の製剂ではあらわれないピークが認められたので, このピークの分離をよくするために，実験方法 3，2） のように測定条件をかえたところ,さらにもう1つの他 の製放ではあらわれないピークが認められた. 検討の結 果, これらのピークはカプセルの成分であるp-ヒドロキ

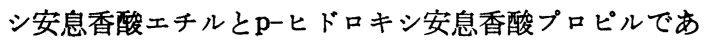
り,これらは保存期間中にカプセルから溶出しているこ とがわかった. そして実験方法 3，1）の測定条件では p-ヒドロキシ安息香酸エチルと I. S. として用いたp-ジ メチルアミノベンズアルデヒドの保持時間が全く同じで あるためにI.S.のピーク面積が過大に測定され，そのた め製剤Eでは実際よりす低いNif.の定量值が得られたる のと推定された（Table 4, Fig. 1).

そこで著者らは実験方法 3，2）の条件で Nif. を定量 したところ，Fig. 2 に示すように製剤Eについて子表 示量值に近い定量值が得られた (Table 5, Fig.2).

したがってカプセルからの溶出物と Nif. の間には相 互作用が扣こっていないものと考えられ，Nif. の薬効

Table 4. Results of Content Variation Test

\begin{tabular}{ccccc}
\hline \hline Preparation & Mean (\%) & Max. (\%) & Min. (\%) & C.V. (\%) \\
\hline A & $102(6.0)$ & 109 & 93 & 5.9 \\
B & $98(5.0)$ & 106 & 89 & 5.1 \\
C & $106(3.0)$ & 110 & 102 & 2.7 \\
D & $101(5.0)$ & 109 & 96 & 5.0 \\
E & $84(4.0)$ & 95 & 81 & 4.8 \\
F & $102(7.0)$ & 111 & 90 & 6.9 \\
\hline
\end{tabular}


Table 5. Results of Content Variation Test

\begin{tabular}{|c|c|c|c|c|}
\hline Preparation & Mean (\%) & $\operatorname{Max} .(\%)$ & Min. (\%) & C.V. (\%) \\
\hline A & $102(6.0)$ & 109 & 93 & 5.9 \\
\hline B & $98(5.0)$ & 106 & 89 & 5.1 \\
\hline C & $106(3.0)$ & 110 & 102 & 2.7 \\
\hline D & $101(5.0)$ & 109 & 96 & 5.0 \\
\hline E & $101 .(5.5)$ & 109 & 95 & 4.9 \\
\hline $\mathbf{F}$ & $102(7.0)$ & 111 & 90 & 6.9 \\
\hline
\end{tabular}

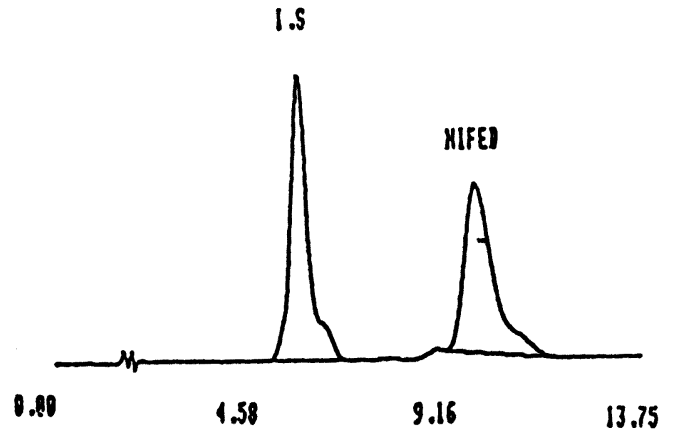

Fig. 1. High-Performance Liquid Chromatogram of Preparation E

は変化しないるのと推定されたが，Nif.製剤の含量試験 にあたっては注意しなければならない問題である。

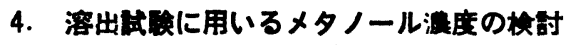

(Fig. 3 参照)

\section{5. 溶出试酸}

溶出試験で行った第 1 液 $70 \mathrm{ml}$ 中における 5 分間の前 操作は，各試料とも第 1 液による平均崩壊時間が約 5 分

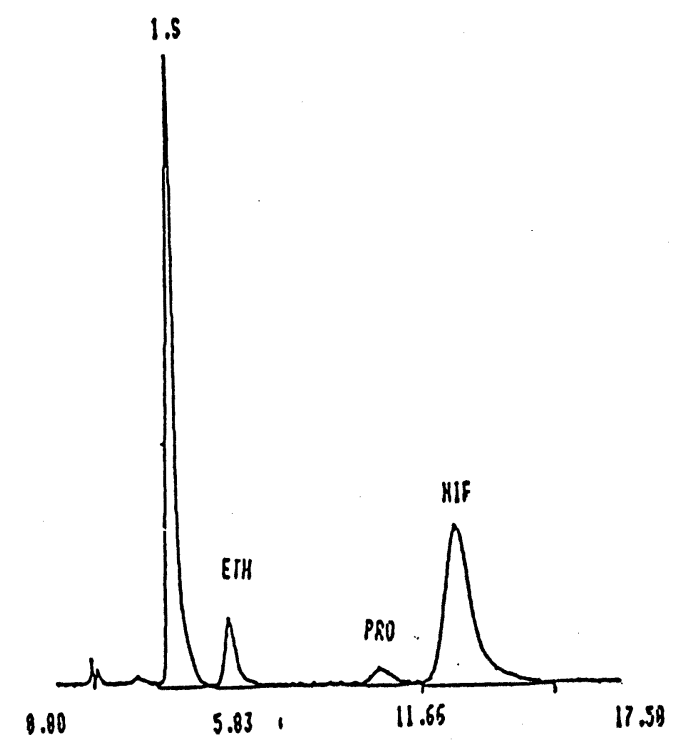

Fig. 2. High-Performance Liquid Chromatogram of Preparation E

であったことを考虑した．

ところでメタノール注入後 5 分に打ける平均溶出率は 最低 $6.0 \%$ ，最高 $47.3 \%$ で各試料間に大きな差がみられ た。また10分後に技ける溶出率は製剂 A, C, D, Eお よびFは良好であったが，Bはやや低かった，Bの溶出 の遅れについては, 崩壊時間が他の製剤に比較して長い ことる原因の一つではないかと考えられた（Fig. 4). 


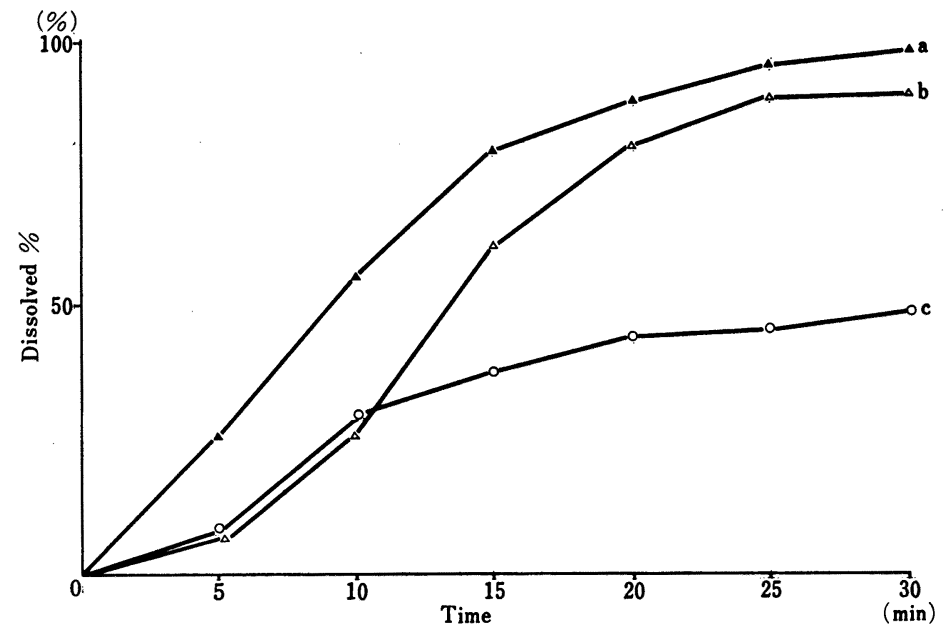

a. the first solution for disintegration test of J.P.X:methanol $=7: 3$ b.

Fig. 3. Investigation of Eluate for Dissolution Test

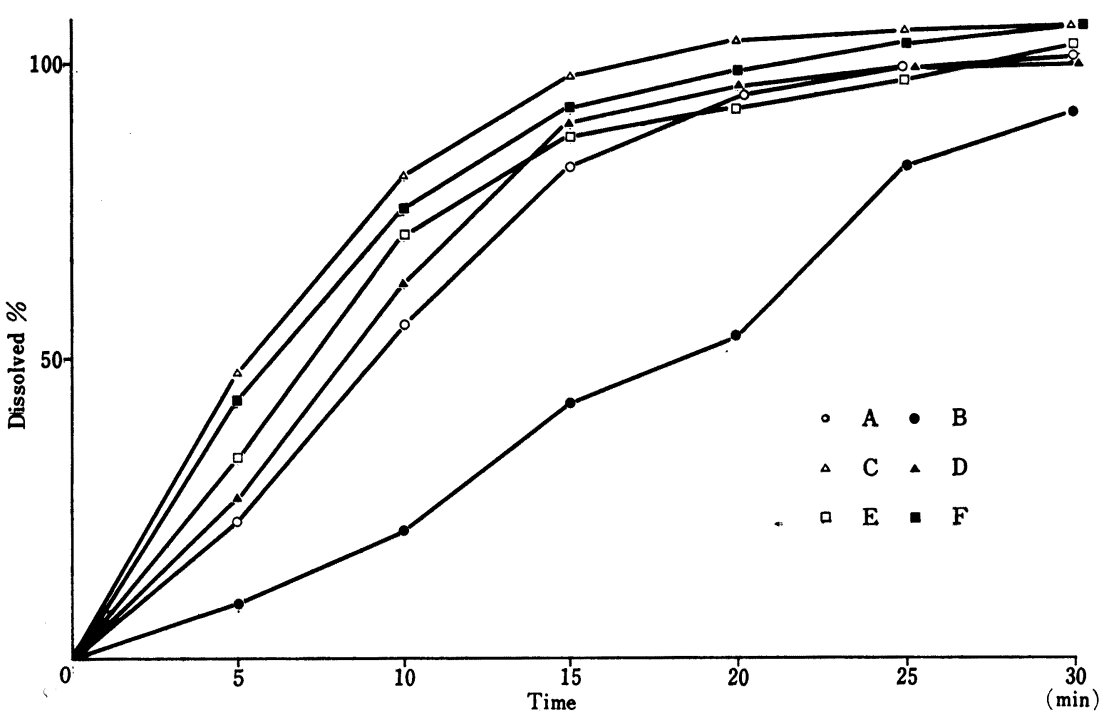

Fig. 4. Dissolution Profiles of Six Kinds of Nifedipine Preparations

ま とめ

著者らは 6 銘柄の Nif. 製剤の品質試験を行ったが， 重量偏差試験および崩壊試験ではいずれる日局の規定に 適合していた。な洂，硬度と崩壊時間の間には相関がる られなかった。また，含量試験では，Nif．の含量はい ずれる表示量に近い値を示したが，1 銘柄だけカプセル に含まれている物質がカプセルの内容物に溶出してきて
おり，このような場合には溶出した物質が定量に影響を およぼしていないかどうか検討する必要がある。

また，溶出試験は第 1 液とメタノールの $7: 3$ （体積 此）の混合溶液を溶出液として行った．その結果, Nif. の溶出率は 5 銘柄では良好であったが，他の 1 銘柄はす べての測定時間において他のものより明らかに低かっ た。 
交

献

1) 佐藤亮, 小林章吾, 伊藤善平, 领島尚志, 野口 実, 関水康彰, 船橋喿一: 薬串新報, No. 1148 , $33 \sim 36$ (1981).
2) 工藤章, 堺純一, 幸野久, 未繁文英, 上山加代子: 基礎と臨床， 6，259 276 (1972).

3) Piergiorgio Pietta, Angelo Rava, and Pierantonio Biondi : Journal of Chromatography, 210, 516 521 (1981).

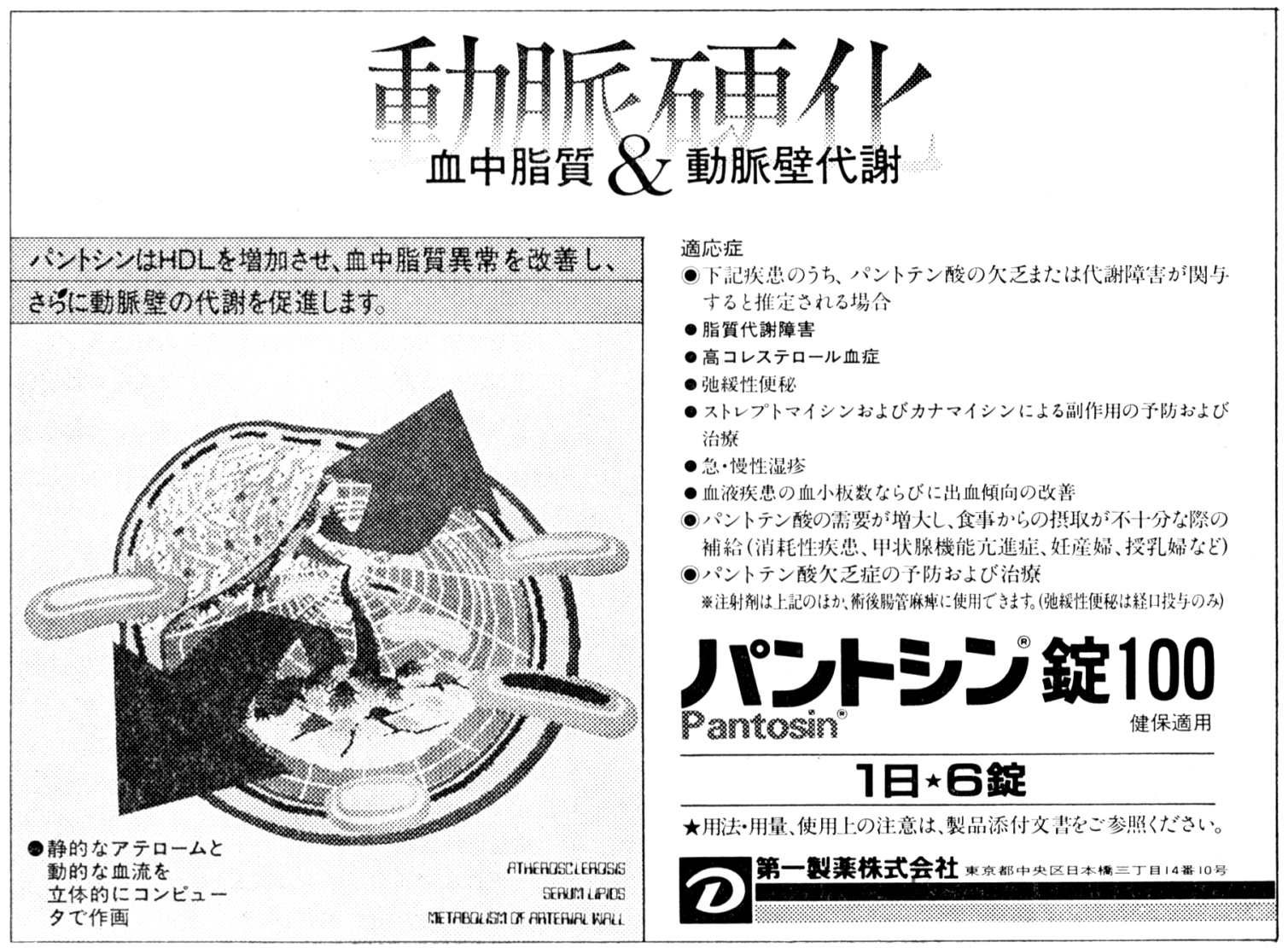

